\title{
KONSELING SPIRITUAL TEISTIK UNTUK MENINGKATKAN KEDISIPLINAN SISWA MTs NEGERI 3 BANDUNG JAWA BARAT
}

\author{
DEDEH KURNIA
}

MTs Negeri 3 Bandung Jawa Barat

Email : dedehkurniamtsn3bandung@gmail.com

\begin{abstract}
ABSTRAK
Penelitian bertujuan mengidentifikasi efektivitas konseling spiritual teiastik untuk meningkatkan kedisiplinan siswa. Penelitian mengguakan metode kuasi eksperimen dengan disain pre test post test group, hasil penelitian menggunkan kolmogorov smirnov test untuk mengetahui signifikansi konseling spiritual teistik terhadap kedisiplinan siswa. Hasil penelitian menunjukkan konseling spiritual teistik efektiktif meningkatkan kedisiplinan siswa. Berdasarkan hasil penelitian rekomendasi ditujukan pada guru bimbingan dan konseling untuk dapat mengaplikasikan konseling spiritual teistik untuk meningkatkan kedisiplinan siswa
\end{abstract}

Kata kunci : konseling spiritual teistik kedisiplinan siswa

\section{PENDAHULUAN}

Remaja pada jenjang pendidikan sekolah menengah pertama tergolong pada usia remaja awal yang berada pada kisaran usia 13 sampai 15 tahun. Secara psikologis remaja awal yang berada pada tahap strum and drunk Syamsuddin, (2004 : 214) menyatakan remaja awal sarat dengan kondisi labil dan tidak konsisten serta mudah terpengaruh oleh lingkungan sehingga remaja memerlukan pendidikan sebagai filter, sehingga remaja dapat tumbuh dan berkembang sesuai potensi diri.

Remaja yang mengikuti proses pendidikan diharapkan dapat tumbuh dan berkembang menjadi individu-individu yang menunjukkan perlaku terdidik yaitu perilaku yang memiliki arah dan tujuan yang jelas dan berorientasi positif dan menunjukkan perilaku yang dilandasi dengan nilai dan moral. Perilaku yang dilandasi moral ditunjukkan remaja dengan kepatuhan dan ketaatan remaja dalam mentaati sejumlah aturan. Kartadinata (2014 : 90) menyatakan orang yang bermoral menyukai kehidupan yang tertib,disiplin,menjungjung tinggi hukum, produktif dan perilaku positif lainnya bukan karena takut penjara atau hukuman.

Perkembangan moral pada remaja menurut Kohlberg (dalam Santrock, 2003 : 457) terdiri dari tiga tahapan yaitu, prakonvensional, konvensional, dan pasca konvensional. Tahap prakonvensional yaitu tahap anak mengenal baik buruk, benar salah suatu perbuatan didasarkan pada sudut konsekwensi (dampak/akibat), tahapan prakonvensional terdiri dari usia anak enam sampai 10 tahun. Tahap konvensional yaitu tahap anak memandang baik buruk, benar salah, atau berharga bagi dirinya apabila dapat memenuhi harapan.persetujuan dari keluarga atau kelompok. Tahap konvensional terdiri dari usia 11-13 tahun. Tahap pasca konvensional adalah tahap individu mengartikan nilai-nilai atau prinsip-prinsip yang dapat diterapkan atau dilaksanakan terlepas dari otoritas kelompok.

Remaja pada usia sekolah menengah berada pada tahap konvensional, yang menilai baik dan buruk didasarkan pada sebuah kelompok atau dengan istilah lain heteronomy. Pada tahap konvensional remaja berkembang sikap loyalitas atau penyesuaian diri terhadap keinginan kelompok termasuk mentaati aturan yang ditetapkan oleh lingkungan.

Aturan yang ditetapkan lingkungan salah satunya adalah tata tertib sekolah. Sekolah bertanggung jawab memfasilitasi remaja untuk mentaati tata tertib dengan cara menegakkan disiplin melalui pemberlakukan sangsi dan hadiah, sekolah biasanya menugaskan wakil kepala sekolah bidang kesiswaan dan staf bimbingan konseling untuk menginformasikan tata tertib dan menegakkan tata tertib sekolah. Upaya penegakkan tata tertib sekolah diartikan sebagai upaya penegakkan disiplin. 
Kemampuan remaja dalam mentaati sejumlah aturan sebagai bukti remaja menjungjung moral menjadi perilaku disiplin. Perilaku disiplin muncul karena remaja memiliki kesadaran diri dan kemampuan dalam mengendalikan diri. Semiawan (2009: 91) mengungkapkan kesadaran diri tampak apabila anak memiliki perhatian terhadap diri dan merasa malu apabila melakukan pelanggaran terhadap aturan tertentu sebagai bentuk proses pembentukan disiplin. Haidar (2013 : 2) menyatakan pengendalian diri merupakan keinginan dan kemampuan dalam menggapai kehidupan yang selaras, serasi dan seimbang pada hak dan kewajibannya sebagai individu dalam kehidupan keluarga, masyarakat, bangsa dan negara.

Remaja yang mampu mengendalikan diri lebih dapat mematuhi peraturan yang diterapkan di sekolah. Sebaliknya remaja yang tidak dapat dalam mengendalikan diri cenderung banyak melakukan pelanggaran terhadap peraturan di sekolah. Kemampuan remaja dalam melakukan pengendalian diri akan berdampak pada kemampuan remaja menunjukkan perilaku disiplin. Musfah (2015 : 1) menyatakan Disiplin adalah kemampuan memanfaatkan waktu untuk melakukan hal-hal yang positif guna mencapai sebuah prestasi. Disiplin juga berarti kemampuan berbuat hanya yang memberikan manfaat bagi diri, orang lain, dan lingkungan. Banyaknya remaja yang menunjukkan perilaku tidak mampu mengendalikan diri yang berdampak tidak disiplin di MTs Negeri 3 Bandung merupakan permasalahan yang harus segera diatasi.

Guru bimbingan dan konseling di MTs Negeri 3 Bandung menunjukkan hampir 70\% siswa terbiasa mengeluarkan kata-kata kotor dan jorok, $70 \%$ tidak mengucap salam jika bertemu dengan guru di jalan, 65\% suka berbohong, 65\% bergaul dengan anak tidak bersekolah, merokok di lingkungan sekolah. Apabila tidak segera diselesaikan akan berdampak terhadap pengendalian diri dalam lingkungan yang lebih luas. Pendekatan bimbingan dan konseling sebagai intervensi yang diharapkan dapat menumbuhkan kedisiplinan pada remaja sehingga remaja mampu menampilkan perilaku yang positif seperti mampu mentaati peraturan sekolah.

Berbagai pendekatan dalam bimbingan dan konseling yang dapat digunakan sebagai bentuk intervensi terhadap remaja yang memiliki masalah ketidakmampuan mengendalikan diri dalam perilaku disiplin, diantaranya : 1) Pendekatan Behavioral yang akan mengubah perilaku remaja melalui peningkatan kondisi baru yang lebih mendukung pada proses belajar remaja; 2) Pendekatan Rational Emotif dapat digunakan sebagai upaya mengubah cara berfikit remaja dari irasional menuju rasional terhadap perilaku yang sering ditampilkan di sekolah; 3) Pendekatan konseling Gestalt yang memandang remaja sebagai sebuah keutuhan sehingga remaja dipandang sebagai pribadi yang baik, dan mampu menangani permasalahan dalam hidup, konseling gestalt membantu remaja agar memperoleh kesadaran diri sehingga mampu menangani masalah-masalah hidup, Darminto (2009 : 42); 4) Pendekatan konseling Spiritual Teistik yang akan berupaya mengintervensi remaja agar remaja mampu menerima tanggungjawab dan memperbaiki kekeliruan perilaku yang kurang baik serta dapat mengembangkan diri dalam kebenaran, (Yusuf, 2009: 42).

Konseling Spiritual Teistik dipilih sebagai pendekatan yang digunakan untuk meningkatkan perilaku disiplin dalam penelitian. Pemilihan pendekatan didasarkan karena remaja yang menjadi sasaran intervensi berada di sekolah dengan label agama (Madrasah Tsanawiyyah) sehingga pendekatan bimbingan dengan muatan agama diprediksi lebih dapat difahami oleh remaja (peserta didik).

Pada dimensi Konseptual, Konseling Spiritual Teistik menurut Yusuf (2009 : 27) memiliki pandangan mengenai manusia sebagai makhluk yang memiliki potensi atau fitrah spiritual religius sehingga mampu merespon nilai-nilai ilahiyah melalui qolbunya dan mengaktualisasikannya dalam rangka mencapai kehidupan personal dan sosial yang sejahtera dan bermakna. Yusuf (2009,hlm.30) selanjutnya individu yang memiliki pemahaman agama yang kuat akan lebih mudah mengalami penyesuaian psikologis dan memiliki perilaku sosial yang sehat. 
Tujuan utama Konseling Spiritual Teistik menurut Yusuf (2009 : 40) individu dapat menerima tanggung jawab dan memperbaiki kekeliruan sikap dan perilakunya yang mementingkan diri sendiri serta dapat mengembangkan diri dalam kebenaran dan komitmen terhadap keyakinan spiritualnya. Penggunaan Konseling Spiritual Teistik untuk meningkatkan disiplin diharapkan membuat peserta didik dapat menerima tanggungjawab dan memperbaiki kekeliruan dengan tidak mentaati sejumlah aturan yang diterapkan di sekolah menjadi mentaati peraturan dan menerima tanggung jawab sebagai bagian dari warga sekolah yang harus terlibat menjaga ketertiban sekolah.

Penelitian meningkatkan perilaku disiplin remaja di MTs Negeri 3 Bandung dilakukan sebagai peran bimbingan dan konseling dalam pengentasan masalah yang berkaitan dengan pengendalian remaja dalam meningkatkan perilaku disiplin. Depdiknas (2007 : 197) menyebutkan tujuan pelayanan bimbingan dan konseling adalah agar konseli dapat : (1) merencanakan kegiatan penyelesaian studi, perkembangan karir serta kehidupannya dimasa yang akan datang; (2) mengembangkan seluruh potensi dan kekuatan yang dimilikinya seoptimal mungkin; (3) menyesuaikan diri dengan lingkungan pendidikan,lingkungan masyarakat serta lingkungan kerjanya; dan (4) mengatasi hambatan dan kesulitan yang dihadapi dalam studi, penyesuaian dengan lingkungan pendidikan, masyarakat, maupun lingkungan kerjanya.

Remaja yang telah memperoleh intervensi dengan menggunakan Konseling Spiritual Teistik diharapkan lebih memiliki kemampuan penyesuaian psikologis dalam mengendalikan diri untuk dapat mentaati rangkaian aturan dari sekolah. Marita (2012 : 4) menyebutkan pengendalian atau pengelolaan diri merupakan merupakan sikap, tindakan atau perilaku seseorang secara sadar baik direncanakan atau tidak untuk mematuhi nilai dan norma sosial yang berlaku. Penelitian mengenai Kedisiplina penting dilakukan sebagai upaya untuk memberikan bantuan agar remaja memiliki kemampuan untuk melakukan perilaku disiplin sebagai wujud dari perilaku terpelajar.

\section{METODE PENELITIAN}

Penelitian menggunakan pendekatan kuantitatif yaitu penelitian yang akan memuat data-data numerikal dan mendeskripsikan data-data mengenai tingkat kedisiplinan yang terdapat pada siswa MTs Negeri 3 Bandung, serta mengukur efektivitas konseling teistik untuk meningkatkan perilaku disiplin. Metode yang digunakan dalam penelitian adalah metode kuasi eksperimen. Penelitian kuasi eksperimen dapat diartikan sebagai penelitian yang mendekati eksperimen atau eksperimen semu, Sugiono (2014 : 77) mengemukakan kuasi eksperimen merupakan penenlitian yang memiliki kelompok kontrol, tetapi tidak dapat berfungsi sepenuhnya mengontrol variabel-variabel luar yang mempengaruhi pelaksanaan eksperimen. Kuasi menjadi disain yang digunakan dalam penelitian karena melalui penelitian kuasi peneliti dapat memperoleh data perbandingan, menegenai efektivitas Konseling Spiritual Teistik melalui eksperimen terhadap kelompok kontrol dan kelompok eksperimen sehingga dapat diperoleh data yang menunjukkan siginifikan pada setiap aspek dan indikator.

Desain eksperimen kuasi yang digunakan adalah nonequlvalent pretest-postest group design, yaitu jenis desain yang biasanya dipakai pada eksperimen yang menggunakan kelaskelas yang sudah ada sebagai kelompoknya, dengan memilih kelas-kelas yang diperkirakan sama keadaan atau kondisinya. Dua kelompok (kontrol dan eksperimen) diberi pretest, kemudian diberikan perlakuan (treatment) berupa pendekatan konseling spiritual teistik untuk meningkatkan kedisiplinan siswa pada kelompok eksperimen sedangkan kelompok kontrol tidak diberi perlakuan, dan selanjutnya diberikan posttest. (Creswell, 2012 : 310). Skema desain penelitian tersaji pada tabel 1.1 
Tabel 1. Quasi-Eksperiment Pretest and Posttest Design

Pre- and Posttest Design

Time

\begin{tabular}{|l|l|l|l|}
\hline Control Group & Pretest & No Treatment & Posttest \\
\hline $\begin{array}{l}\text { Eksperimental } \\
\text { Group }\end{array}$ & Pretest & $\begin{array}{l}\text { Eksperimental } \\
\text { Treatment }\end{array}$ & Posttest \\
\hline
\end{tabular}

Keterangan:

Control Group

Eksperimental Group

No Treatment

Eksperimental Treatment $\quad=$ Pemberian perlakuan $($ Creswell, $2012: 310)$

$=$ kelompok kontrol

$=$ kelompok eksperimen

$=$ Tanpa perlakuan

desain pre test po

Metode kuasi eksperimen yang dilakukan melalui desain pre test post test control group (pre test post tes dua kelompok) untuk memperoleh gambaran mengenai efektivitas intervensi yang dilaksanakan secara sistematis melalui konseling spiritual teistik dalam meningkatkan perilaku disiplin siswa MTs Negeri 3 Bandung.

\section{HASIL PENELITIAN DAN PEMBAHASAN}

Pengujian efektivitas konseling spiritual teistik untuk meningkatkan kedisiplinan siswa dilakukan dengan menggunakan teknik komologrov sminar test. Hasil penghitungan statistik dengan teknik komologrov sminar test memberikan kesimpulan pendekatan konseling spiritual teistik secara umum signifikan meningkatkan kedisiplinan siswa namun terdapat hasil yang tidak signifikan pada mengenai kepatuhan dan pada indikator mengenai bersedia menerima sanksi apabila melanggar norma dan mengenai kemampuan menjalankan aturan dengan penuh tanggung jawab. Secara rinci hasil pengolahan data dengan menggunakan Kolomogorof Smirnov Test akan dipaparkan pada tabel 2 di bawah ini :

Tabel 2. Hasil Uji Kolmogorov Smirnov Test

\begin{tabular}{|l|l|l|l|l|}
\hline No & \multicolumn{1}{|c|}{ Uraian } & $\begin{array}{l}\text { Kolomogorov } \\
\text { Smirnov Test }\end{array}$ & P & Keterangan \\
\hline 1. & Total & 2.646 & 0,00 & Signifikan \\
\hline 2 & Aspek Pengendalian diri & 2,642 & 0,00 & Signifikan \\
\hline 3. & Aspek Sikap & 1,701 & 0,06 & Signifikan \\
\hline 4. & Sub Aspek, Kepatuhan & 2,646 & 0.00 & Signifikan \\
\hline 5. & SubAspek, Ketaatan & 2,457 & 0,00 & Signifikan \\
\hline 6. & Sub Aspek Kepatuhan & 1,512 & 0,21 & Tidak Signifikan \\
\hline 7. & Sub Aspek Ketaatan & 2,079 & 0,00 & Signifikan \\
\hline $8 .$. & $\begin{array}{l}\text { Mampu menunjukkan } \\
\text { perilaku yang selaras } \\
\text { dengan norma }\end{array}$ & 1,701 & 0,06 & Signifikan \\
\hline 9. & $\begin{array}{l}\text { Mampu menjalankan } \\
\text { kewajiban yang selaras } \\
\text { dengan aturan }\end{array}$ & 2,457 & 0,00 & Signifikan \\
\hline 10. & $\begin{array}{l}\text { Bersedia menerima sanksi } \\
\text { apabila melanggar norma }\end{array}$ & 3,78 & 999 & Tidak Signifikan \\
\hline
\end{tabular}




\begin{tabular}{|l|l|l|l|l|}
\hline 11. & $\begin{array}{l}\text { Bersedia menerima sanksi } \\
\text { apabila melanggar aturan }\end{array}$ & 1,134 & 153 & Tidak Signifikan \\
\hline 12. & $\begin{array}{l}\text { Kemampuan menjalankan } \\
\text { norma dengan penuh } \\
\text { tanggung jawab }\end{array}$ & 1.890 & 0,02 & Signifikan \\
\hline 13. & $\begin{array}{l}\text { Kemampuan menjalankan } \\
\text { aturan dengan penuh } \\
\text { tanggung jawab }\end{array}$ & 1,323 & 0,60 & Tidak Signifkan \\
\hline 14. & $\begin{array}{l}\text { Menjalankan norma tanpa } \\
\text { paksaan dari orang lain }\end{array}$ & 2,079 & 0,00 & Signifikan \\
\hline 15. & $\begin{array}{l}\text { Menjalankan aturan tanpa } \\
\text { paksaan dari orang lain }\end{array}$ & 1,701 & 0,06 & Signifikan \\
\hline 16. & $\begin{array}{l}\text { Kecenderungan untuk } \\
\text { melaksanakan perilaku } \\
\text { disiplin berdasarkan } \\
\text { keyakinan diri }\end{array}$ & $\begin{array}{l}\text { Kecenderungan untuk } \\
\text { melakukan perilaku } \\
\text { disiplin menurut norma } \\
\text { sesuai kemampuan }\end{array}$ & 0,02 & Signifikan \\
\hline 17.268 & 0,00 & Signifikan \\
\hline
\end{tabular}

Data hasil penghitungan kolmogorov smirnov test menunjukkan satu aspek penelitian mengenai ketaatan tidak signifikan karena harga $\mathrm{p}>$ dari 0,05 , yaitu 1,512 dengan harga $\mathrm{p}$ 0,21, demikian pula dengan indikator 1.c, mengenai bersedia menerima sanksi apabila menerima norma dengan nilai 3,78 harga $\mathrm{p}$,999, indikator 1.d bersedia menerima sanksi apabila melanggar aturan dengan nilai 1,134 dengan harga 153, dan indikator mengenai kemampuan menjalankan aturan dengan penuh tanggung jawab dengan nilai 1,323 dengan harga $\mathrm{p} 0,60$, karena harga $\mathrm{p}>$ dari 0,05 maka indikator dinyatakan tidak signifikan.

Keberhasilan konseling teistik untuk meningkatkan kedisiplinan siswa dipengaruhi oleh faktor lain yang membentuk perilaku disiplin siswa. Dari hasil penelitian ada empat indikator yang tidak efektif, indikator tersebut adalah sub aspek kepatuhan, kemampuan siswa dalam bersedia menerima sanksi apabila melanggar norma, kemampuan siswa dalam bersedia menerima sanksi apabila melanggar aturan, dan kemampuan menjalankan aturan dengan penuh tanggung jawab. Fungsi konseling sebagai preventif bagi siswa-siswa yang membutuhkan segera penyelesaian masalah. Dari empat indikator yang tidak signifikan mengartikan tindakan konseling bukan satu-satunya cara menyelesaikan satu permasalahan, melainkan perlu adanya pengantar lebih dahulu pada siswa berupa pemahaman konsep disiplin melalui bimbingan yang terintegrasi pada semua kegiatan bimbingan di sekolah, sehingga siswa mampu memiliki kemampuan untuk mengendalikan diri agar mampu menunjukan perilaku disiplin di sekolah.

Penegakkan disiplin di sekolah merupakan aspek yang penting dilakukan sebagai wujud dari tanggung jawab yang diberikan guru untuk siswa. Guru dituntut untuk menumbuhkan pengendalian diri dan kepercayaan diri sebagai kebutuhan yang harus dimiliki oleh peserta didik sehingga peserta didik mampu untuk menunjukkan perilaku yang disiplin. Sonia (2013 : 17) menyatakan pengendalian diri dan kepercayaan diri merupakan unsur penting untuk pengelolaan disiplin di sekolah.

Disiplin menurut Sonia (2003 : 17) merupakan kemampuan untuk melakukan tindakan secara efektif dan efisien didasari oleh kemampuan individu untuk mengendalikan diri sehingga mampu menunjukkan perilaku yang disiplin. Indikator yang jelas dari kemampuan individu memiliki pengendalian diri dalam berperilaku disiplin adalah dengan kemampuan 
individu dalam menampilkan batas-batas perilaku yang dapat diterima oleh lingkungan tanpa paksaan dari orang lain.

Penegakkan kedisiplinan akan memunculkan masalah jika tidak adanya dukungan dari seluruh unsur yang dapat berpengaruh terhadap perkembangan siswa. Kebijakan sekolah, peran guru, orang tua dalam memahami perkembangan peserta didik dapat menjadi penunjang utama dalam upaya menumbuhkan kemampuan pengendalian diri pada peserta didik. Sonia (2013 : 18) ketidakmampuan siswa dalam mengendalikan diri akan memunculkan perilaku yang tidak kooperatuf di sekolah seperti : frustasi, mengganggu orang lain, melanggar aturan dan bentuk-bentuk perilaku negatif lainnya.

Salah satu upaya yang dilakukan agar siswa dapat memiliki kemampuan pengendalian diri sehingga memunculkan perilaku disiplin melalui pendekatan konseling spiritual teistik. Konseling menurut Colledge (2002 : 2) sebagai hubungan membantu yang dilakukan konselor untuk menghasilkan perubahan yang terjadi pada klien (konseli). Surya (2009 : 28) konseling bagi konseli dalam rentang yang normal merupakan lingkungan yang dapat membantu memperbaiki keadaan sehingga dari hubungan yang bersifat membantu dan sebagai proses psikologis, konseling memberikan pengalaman baru kepada klien. Konseling juga merupakan lingkungan yang dapat memberikan pengaruh untuk mengurangi hambatan ke arah yang lebih baik, Colledge (2002 : 3) menyebutkan tujuan konseling dilakukan mengganti hal yang negatif dengan sesuatu yang positif, kesehatan mental dan masalah psikologis menjadi hal utama dalam proses konseling.

Konseling spiritual teistik merupakan pendekatan dengan yang dilakukan dengan menggunakan prinsip-prinsip agama dengan tujuan untuk menerima tanggung jawab dan memperbaiki kekeliruan sikap dan perilaku yang mementingkan diri sendiri (Yusuf, 2009 : 40). Intervensi yang dilakukan peneliti dengan menggunakan konseling teistik mengarahkan siswa untuk dapat memandang positif terhadap aturan dan norma di sekolah sehingga siswa dapat menunjukkan perilaku yang disiplin. Proses intervensi dengan konseling spiritual teistik konseli diarahkan melalui teknik-teknik konseling spiritual teistik yang mendorong konseli memiliki keputusan-keputusan akhir dalam bersikap sesuai dengan prinsip agama islam.

Melalui konseling spiritual teistik siswa didorong untuk meningkatkan aktivitas beribadah (menjalankan perintah agama) karena orangh yang memiliki intensitas tinggi dalam ibadah cenderung akan menjauhi perilaku yang tidak sehat, Yusuf (2009 : 29)menyebutkan orang yang aktif dalam keagamaan cenderung dapat memiliki tingkat yang rendah untk terserang penyakit dan dapat menjauhi perilaku yang tidak sehat, seperti merokok. Intervensi yang diberikan melalui konseling spiritual tesitik diharapkan dapat meningkatkan aktivitas keagaamaan siswa, siswa secara lebih jauh dapat memaknai hakekat dan tujuan hidup sehingga siswa secara langsung dapat menjauhi aktivitas-aktivitas yang dinilai bukan bagian dari ajaran keagamaan. Teknik pemberian informasi spiritual memberikan wawasan spiritual terhadap konseli sehingga konseli memahami konsep keagamaan yang berkaitan dengan perilaku disiplin sehingga dapat menghindari perilaku yang tidak mencerminkan perilaku disiplin di sekolah. Teknik lain yang digunakan dalam konseling spiritual teistik adalah teknik doa melalui teknik doa konseli didorong untuk memohon kepada Allah SWT agar dimudahkan dalam melakukan perbaikan perilaku sehingga konseli menyakini kemudahan dalam perubahan perilaku dalam diri didasari oleh usaha dan doa.

Hurlock (Yusuf, 2012 : 54) sekolah merupakan faktor penentu bagi perkembangan kepribadian siswa baik dalam cara berfikir, bertindak maupun cara berperilaku. Sekolah dapat diartikan sebagai rumah kedua bagi siswa dalam mengembangkan kemampuan akademik dan keterampilan sosial. Ratter (Yusuf, 2012 : 55) menyebutkan sekolah efektif merupakan sekolah yang memajukan, meningkatkan atau mengembangkan prestasi akademik, keterampilan sosial, sopan santun, sikap positif terhadap belajar. Paparan definisi sekolah menunjukkan bahwa sekolah memiliki peranan yang besar dalam upaya mengembangkan kepribadian siswa termasuk dalam menumbuhkan kemampuan untuk memiliki perilaku 
disiplin. Konseling Spiritual tesitik melalui teknik-teknik yang digunakan diharapkan dapat merubah cara berfikir konseli yang awalnya memandang perilaku disiplin sebagai tindakan yang biasa dilakukan dan bukan sebuah kekeliruan maka setelah diintervensi melalui konseling spiritual teistik konseli diharapkan dapat mengubah cara pandang mengenai batasan perilaku sebagai pilihan yang tepat dalam bersikap di sekolah.

Penelitian merujuk pada sebuah konsep kedisiplinan yang dikemukakan oleh Tu'u (Riyadi 2013 : 27) disiplin sebagai pengendalian diri dan sikap individu atau masyarakat dalam mengembangkan kepatuhan dan ketaatan terhadap peraturan berdasarkan dorongan dan kesadaran yang muncul dalam hatinya. Perilaku disiplin juga dinilai sebagai salah satu karakter yang harus dikembangkan, Sukitman, (2014 : 72) menyatakan disiplin sebagai salah satu hal yang harus dikembangkan sebagai nilai pembentuk karakter, disiplin dimaknai sebagai tindakan yang menunjukkan perilaku tertib dan patuh pada berbagai ketentuan dan peraturan. Sekolah menjadi salah satu tempat yang dinilai dapat memfasilitasi siswa untuk mengembangkan kemampuan menunjukkan perilaku disiplin dengan menaati aturan dan norma yang berlaku, oleh karena itu sekolah harus memiliki perencanaan yang matang untuk menumbuhkan perilaku disiplin terhadap siswa .

Penegakkan kedisiplinan tidak dapat dilakukan oleh satu pihak yang dapat mempengaruhi siswa field \& Boesser (1994: 9) keterlibatan orang tua dan guru akan memberikan kontribusi positif terhadap siswa untuk menerapkan kedisiplinan. Dengan demikian orang tua dan guru memiliki porsi yang sama dalam menegakkan kedisiplinan, orang tua berperan pada penegakkan kedisiplinann di rumah, sedangkan guru berupaya meneggakkan kedisiplinan dalam lingkup sekolah, peran guru dan orang tua mengenai kedisiplinan harus dikomunikasikan untuk saling mengetahui keadaan siswa ketika berada di rumah maupun ketika berada di sekolah,Bernhardl (1964 : 111) memaparkan komunikasi yang efektif antara guru dan orang tua merupakan hal yang penting dalam pola pendidikan yang modern, orang tua dan guru saling menginformasikan tentang keadaan ataupun masalah yang dihadapi siswa. Komunikasi yang terjalin antara orang tua dan guru di MTs Negeri 3 Bandung berdasarkan hasil pengamatan, komunikasi dengan orang tua hanya berlangsung ketika anak memiliki masalah di sekolah dan belum ada sosialisai mengenai aturan yang berlaku di sekolah terhadap orang tua.sehingga dimungkinkan peran orang tua dan guru dalam penegakkan kedisiplinan memiliki standar yang berbeda sehingga menimbulkan kebingungan pada siswa dalam upaya menunjukkan perilaku disiplin sehingga hasil yang didapatkan tidak signifikan. Lickona (2012 : 196) memaparkan rencana sekolah seharusnya disosialisasikan kepada orang tua sehingga orang tua memiliki peran yang sama dalam membentuk karakter siswa. Syamsuddin (2009 : 139) adanya program parent teacher association (hubungan rumah dengan sekolah), untuk mendekatkan dan dan menyelaraskan sistem nilai yang dikembangkan. Apabila sekolah dan orang tua dapat berkolaborasi dengan baik dalam upaya mengarahkan siswa untuk dapat menunjukkan perilaku disiplin maka perilaku disiplin akan semakin mudah dimiliki oleh siswa.

Bernhandl (1964 : 31) menyatakan pertumbuhan disiplin sangat ditentukan oleh peran orang tua dirumah yang membimbing dan mengarahkan siswa sejak dini. Orang tua sebagai orang terdekat dengan siswa akan memberikan kontrol langsung terhadap perilaku siswa di rumah melalui pengamatan langsung pada perilaku-perilaku yng dimunculkan siswa di rumah.

Lickona (2012 : 196) memaparkan sejumlah tindakan yang perlu dilakukan orang tua dan sekolah dalam menerapkan perilaku disiplin, yaitu :

1. Guru/ pihak sekolah memberikan rencana disiplin yang seharusnya dilakukan seorang siswa disekolah sehingga orang tua dapat mengetahui dan meniskusikan dengan anakanaknya di rumah, sehingga orang tua mengetahui perilaku yang diharapkan siswa di sekolah dan meengetahui resiko yang dihadapi apabila tidak menaati aturan yang berlaku

2. membangun hubungan positif dengan orang tua. Hubungan positf dapat dilakukan guru dengan sekolah sejak pertama kali masuk menjadi siswa, hubungan positif dengan orang 
tua sangat diperlukan karena akan saling memberikan kontrol perilaku disiplin baik di rumah maupun di sekolah.

3. memberitahu orang tua akan masalah disiplin baik pelanggaran yang dilakukan siswa maupun perilaku positif yang telah ditunjukkan siswa.

4. bertemu secara tatap muka dengan orang tua siswa dilakukan tidak hanya ketika siswa memiliki permasalahan di sekolah

5. mengimplementasikan rencana menumbuhkan perilaku disiplin dengan tujuan yang sama yaitu mengembangkan perilaku disiplin siswa.

Pola kerja sama yang dilakukan sekolah dan orang tua penting dilakukan untuk meningkatkan perilaku disiplin siswa, karena perilaku disiplin merupakan perilaku yang harus dimiliki oleh siswa sebagai kemampuan siswa dalam mengekplorasi perilaku positif yang diharapkan dapat berpengaruh untuk mempersiapkan kehidupn pada masa yang akan datang. Erikson (Santrock, 2003 : 47) ekplorasi positif yang dilakukan secara sehat dan mendapatkan jalan positif akan melahirkan identitas positif dan bila ekplorasi positif tidak dapat dilakukan maka akan melahirkan kekacauan identitas. Erikson (Yusuf, 2012 : 71) memandang usia remaja berada pada keadaan moratorium, yaitu periode pada saat remaja diharapkan mampu mempersiapkan untuk masa depan dan mampu menjawab "siapa saya"? dan Erikson mengingatkan kegagalan remaja untuk menuntaskan tugas ini akan berdampak negatif pada perkembangan dirinya. Perilaku disiplin yang dikembangkan remaja sebagai siswa diharapkan dapat membuat siswa dapat mempersiapkan masa depan dengan baik dan dapat memberikan pengaruh positif terhadap perkembangan siswa pada tahap selanjutnya. Bernhardl (1964 : 300) menyatakan perilaku disiplin merupakan bagian dari kesehatan mental, orang tua dan guru harus sama-sama memberikan kontrol perilaku terhadap remaja agar remaja memiliki kesehatan mental yang kuat. Meskipun sekolah merupakan tempat yang tepat untuk mengajarkan siswa menjadi pribadi terdidik akan tetapi keterlibatan orang tua dalam penegakkan kedisiplinan merupakan hal yang sangat penting.

Keterlibatan guru, orang tua dan lingkunga akan membentuk siswa yang memiliki karakter disiplin, Yustiana ( TT, hlm.1) memaparkan orang yang memiliki karakter disiplin yang ssehat adalah orang yang mampu melakukan fungsi psikososial dalam berbagai setting termasuk : 1) kompetensi bidang akademik, pekerjaan dan relasi sosial; 2) pengelolaan emosi dan mengontrol perilaku-perilaku yang impulsif; 3) kepemimpinan; 4) harga diri yang positif dan identitas diri. Disiplin dapat diukur atau diobservasi baik secara emosional maupun tampilan perilaku. Disiplin berfungsi menyeimbangkan antara indenpensi, tindakan yang percaya diri dan hubungan positif dengan orang lain agar perkembangan dan mampu menyesuaikan diri secara optimal.

Pengaruh lain yang terkait dengan penegakkan disiplin yaitu perkembangan

moral, seseorang yang matang dalam perkembangan moral dimungkinkan akan sangat mudah menunjukkan perilaku disiplin, sebaliknya apabila sesorang belum matang dalam perkembangan moral dimungkinkan akan mengalami kesulitan dalam menunjukkan perilaku disiplin di sekolah. Santrock (2003 : 452) anak yang memiliki pemahaman moral cenderung tidak berbuat curang dalam situasi yang menuntut dirinya bertahan menghadapi suatu godaan dibandingkan dengan anak yang tidak memiliki prinsip yang kuat.

Bernhardl (1964 : 9) menyebutkan sebagian orang memaknai disiplin secara sempit yaitu perilaku yang keras, takut, sakit dan khawatir padahal disiplin adalah sebuah perilaku yang positif untuk memberikan koreksi, sehingga penerapan disiplin memerlukan perencanaan yang dilakukan sekolah. Bernhardl (1964: 7) disiplin diartikan sebagai sebuah bagian dari perencanaan dalam sebuah pelatihan bukan hanya sebuah koreksi atau hukuman. Pendekatan secara positif sangat ditekankan seperti dukungan, penerimaan serta afeksi menjadi bagian dari sebuah perencanaan sehingga hukuman bukan lagi sebagai teknik yang digunakan akan tetapi bimbingan, binaan dan pengontrolan menjadi bagian yang digunakan dalam pendekatan penerapan disiplin. Disiplin dengan perencanaan yang baik akan 
melahirkan situasi belajar dan hidup yang sehat. Selain itu perilaku disiplin membutuhkan pengontolan dan bimbingan yang dilakukan terhadap siswa.

Bimbingan dan pengontrolan perlu dilakukan terhadap siswa dalam upaya penerapan disiplin karena siswa secara umum berada pada rentang usia remaja awal yang sedang mengalami masa kritis yang labil sehingga memungkinkan remaja memunculkan perilaku yang tidak disiplin. Pendekatan konseling spiritual teistik dapat digunakan dalam upaya menumbuhkan perilaku disiplin pada siswa secara terprogram agar siswa memiliki perkembangan disiplin secara optimal.

\section{KESIMPULAN}

Hasil penelitian menunjukkan bahwa Konseling Spiritual Teistik efektif untuk meningkatkan kedisiplinan siswa .Keefektifan ditandai dengan data hasil penghitungan statistik kenaikan pada aspek maupun indikator. Bukti efektivitas konseling spiritual teistik ditampilkan dalam bentuk perubahan-perubahan konseli yang terrekam pada lembar kerja yang diisi oleh siswa yang menunjukkan konseli mampu untuk menyelesaikan hambatan/masalah dan membuat strategi perubahan perilaku ke arah yang lebih baik.

Perubahan siswa dapat ditunjukkan dengan komintmen yang dituliskan dalam lembar kerja siswa dan direalisasikan dalam kehidupan di sekolah. Perubahan perilaku yang secara nyata dapat ditunjukkan oleh siswa, antara lain :

a. Siswa lebih menghargai waktu dan tidak datang terlambat ke sekolah

b. Siswa lebih dapat menghargai keberdaan diri dan orang lain di sekolah

c. Siswa memahami apabila melanggar aturan akan dihadapkan pada resiko sanksi yang dihadapi, oleh sebab itu siswa berupaya untuk tidak melanggar aturan di sekolah.

d. Siswa melakukan perubahan didasari oleh keinginan diri sendiri bukan karena orang lain

\section{REKOMENDASI} didik yaitu .

Rekomendasi penelitian diperuntukkan bagi pihak-pihak yang terkait dengan peserta

1. Guru Bimbingan dan Konseling (BK)

Pendekatan konseling spiritual teistik dapat digunakan sebagai salah satu pendekatan yang dapat digunakan guru BK dalam melakukan konseling dalam menyelesaikan masalah kedisiplinan di sekolah. Guru BK dapat melaksanakan pendekatan konseling spiritual tesirik dengan mengikuti panduan pelaksanaan konseling spiritual tesitik untuk meningkatkan kedisiplinan siswa, panduan terlampir.

2. Peneliti Selanjutnya

Penelitian terbatas pada populasi MTs Negeri, peneliti selanjutnya dapat meneliti dengan ruang lingkup yang lebih luas atau dengan karakteristik sampel penelitian yang berbeda untuk mendapatkan hasil yang lebih variatif

\section{DAFTAR PUSTAKA}

Berhardl. L, K. (1964). Discipline and Child Guidance. USA. All Right Reserved

Bolford. S. (1998). Managing discipline in the School. USA : Routladge

Colledge. R. (1998). Mastering Counseling Theorz. New York : Palgrave Macmillan

Creswell. J.W. (2012). Education Reseacrh Palning Conducting and Evaluating Quantitative and Qualitative Research (3 end) New Jersey. Pason Education.Inc.

Darminto, E. (2007). Teori dan Praktek Konseling dari berbagai orientasi dan Pendekatan. Surabaya :Unesa. University Press

Depdiknas .(2008).Penataan Pendidikan Profesional Konselor dan Layanan Bimbingan dan Konseling dalam Jalur Profesional 
Haidar. (2013). Kecerdasan emosi dan Pengendalian Diri [on line] diakses. Httphaidar woorpress

Hurlock. E. (2004). Psikologi Perkembangan Sepanjang Rentang Kehidupan. Jakatra:. Erlangga

Julia, F., (2013). Disiplin Siswa di Sekolah dan Implikasinya dalam Pelayanan Bimbingan dan Konseling. Jurnal Bimbingan dan Konseling. Universitas Negeri Padang Volume 2

Kartadinata, S. (2014) Politik Jati Diri : Telaah filosofi dan Praktis Pendidikan bagi Penguatan jati diri bangsa, Bandung : Universitas Pendidikan Indonesia

Lickona . T (2013). Educating For Character. Bagaimana sekolah dapat mengajarkan sikap hormat dan tanggung jawab. Jakarta : Bumi Aksara

Marita Y (2013). Manfaat Pengendalian Diri. (on line) diakses di http maritayuliablog/ pengendalian diri

Musfah. J. (2015). Pengertian Disiplin [on line] tersedia httpakademis.com. diakses 13 maret 2015

Santrock. J. W (2003). Adolesence Perkembangan Remaja. Jakarta : Erlangga

Semiawan. C. (2009) Penerapan Pembelajaran pada Anak. Jakarta : Erlangga

Surya M (2011) Bimbingan untuk Mempersiapkan Generasi Muda Memasuki Abad 21 (Pendekatan Psikopedagogis) Bandung : UPI Press

Surya M (2003). Psikologi Konseling. Bandung : Maestro

Syamsudin A (2009). Psikologi Kependidikan Perangkat Sistem Pengajaran Modul. Bandung : Remaja Rosda Karya

Yustiana. YR. (2012) Perkembangan Disiplin. PPB : Universitas Pendidikan Indonesia

Yusuf, S. (2004), Psikologi Perkembangan Anak dan Remaja. Bandung : Rosda Karya

Yusuf, S, (2009) Konseling Teistik. Remaja, Bandung : Rizki Press 